\title{
Ecology of the parasitic endohelminth community of Pseudoplatystoma fasciatum (Linnaeus, 1776) (Siluriformes: Pimelodidae) from the Aquidauana River, Pantanal, State of Mato Grosso do Sul, Brazil
}

\author{
Campos, CM. ${ }^{\mathrm{a}, \mathrm{c} *}$, Fonseca, VE. ${ }^{\mathrm{a}}$, Takemoto, RM. ${ }^{\mathrm{b}}$ and Moraes, FR. ${ }^{\mathrm{c}}$ \\ ${ }^{a}$ Unidade Universitária de Aquidauana, Universidade Estadual de Mato Grosso do Sul - UEMS, \\ Rod. Aquidauana-CERA, Km 12, Zona Rural, CEP 79200-000, Aquidauana, MS, Brazil \\ bNupélia, Universidade Estadual de Maringá - UEM, \\ Av. Colombo, 5790, Bloco G-90, CEP 87020-900, Maringá, PR, Brazil \\ ${ }^{c}$ Centro de Aqüicultura, Campus de Jaboticabal, Universidade Estadual Paulista Júlio de Mesquita Filho - UNESP, \\ Rod. Paulo Donato Castellani, Jaboticabal, SP, Brazil \\ *e-mail: cmeldau@uems.br \\ Received: February 6, 2008 - Accepted May 9, 2008 - Distributed February 28, 2009
}

\begin{abstract}
This study investigated the structure and diversity of the endohelminth community and its interactions with Pseudoplatystoma fasciatum, caught in the Aquidauana River, in the State of Mato Grosso do Sul, Brazil. Ten helminth species were represented in 1,228 specimens of parasites found in the intestine and mesentery of 33 specimens of P. fasciatum. Cestodes were observed in the intestine, while nematodes Cucullanus sp. in the mesentery. Contracaecum sp. Type 1, Spatulifer rugosa and Choanoscolex abscisus showed the highest mean intensity and mean abundance and Nomimoscolex sudobin showed the highest prevalence. Simpson's index indicated dominance in the endohelminth infracommunities $(\mathrm{C}=1.0792)$ and Choanoscolex abscisus was considered the central species. A clumped pattern of dispersion according to Green's index was related. $69.69 \%$ of hosts analyzed had between 2 and 5 species of endohelminths. Mean diversity was $\mathrm{H}=0.5517$ ( $\mathrm{SD}=0.4209)$. Two pairs of species showed significant positive association and four pairs presented significant positive correlation among abundance data. Significant negative correlations between total length and prevalence and abundance of Peltydocotyle rugosa and Nomimoscolex sudobim were found. However, no significant correlation was observed between condition factor and abundance, as well as total length and diversity. There was significant prevalence of Harriscolex kaparari in male hosts.
\end{abstract}

Keywords: ecology, helminths, fish, Pantanal, Pseudoplatystoma fasciatum.

\section{Ecologia da comunidade parasitária endohelmíntica de Pseudoplatystoma fasciatum (Linnaeus, 1776) (Siluriformes: Pimelodidae), do Rio Aquidauana, Pantanal, Mato Grosso do Sul, Brasil}

\begin{abstract}
Resumo
Neste trabalho foram descritas a estrutura e diversidade da comunidade endohelmíntica e suas interações com Pseudoplatystoma fasciatum, capturados no rio Aquidauana, MS. Foram encontrados 1.228 espécimes de helmintos, representados por dez espécies, parasitando intestino e mesentério de 33 espécimes de $P$. fasciatum. Todos os cestodas parasitavam o intestino e, o nematoda Cucullanus sp. foi encontrado no mesentério. Contracaecum sp. Tipo 1, Spatulifer rugosa e Choanoscolex abscisus apresentaram os maiores valores de intensidade média e abundância média, respectivamente e, juntamente com Nomimoscolex sudobim foram as mais prevalentes. O índice de Simpson indicou dominância entre as infracomunidades de endohelmintos $(\mathrm{C}=1,0792)$ e Choanoscolex abscisus foi considerada espécie central. Foi observado um padrão de distribuição agregado de acordo com o índice de Green. Dos hospedeiros amostrados 69,69\% continham entre duas a cinco espécies. A diversidade média encontrada foi de $\mathrm{H}=0,5517$ ( $\mathrm{DP}=0,4209)$. Dois pares de espécies apresentaram associações positivas significativas e quatro pares apresentaram correlações positivas significativas entre as abundâncias. Foram observadas correlações negativas significativas entre comprimento total e prevalência e abundância parasitária para Peltydocotyle rugosa e Nomimoscolex sudobim. Não houve correlação significativa entre fator de condição e abundância parasitária, comprimento total e diversidade. A prevalência de Harriscolex kaparari foi significativamente maior nos hospedeiros machos.
\end{abstract}

Palavras-chave: ecologia, helmintos, peixes, Pantanal, Pseudoplatystoma fasciatum. 


\section{Introduction}

The composition of fish parasitic fauna, in general, depends on the habitat geography, season of the year, water characteristics, fauna present, direct activity area and parasite environment (Dogiel, 1970). The structure of several parts of the digestive tract, organ histology and the spatial relationship among organs are also factors that determine infections of several endohelminth species (Dogiel, 1970).

Studies referring to the taxonomy and ecological aspects of fish parasites, in the Paraná river basin, are common. However, there are few papers regarding this subject in the Pimelodidae family, particularly from the Pantanal region in the State of Mato Grosso do Sul.

The species of the genus Pseudoplatystoma are rarely studied. Machado et al. (1996) analyzed the relationship between endohelminth species and its hosts, among them Pseudoplatystoma corruscans, a carnivore Pimelodidae found in South America. Specimens of P. corruscans, collected in the Paraná River, by Machado et al. (1996) presented higher prevalence of infection by cestodes and low intensity infection by nematodes, without, however, dominance in the endo-parasitic fauna.

Studies on Pseudoplatystoma species from the Pantanal region, MS, usually consist of a database of parasite species and respective prevalence, with no emphasis on the parasite community ecology. Santos et al. (2003) reported high prevalence of cestodes and nematodes in the intestines of Pseudoplatystoma fasciatum and $P$. corruscans captured in the rivers Aquidauana, Miranda and Paraguay, in South Pantanal.

This paper aims at describing the structure and diversity of the endohelmintic community and its interactions with the host Pseudoplatystoma fasciatum, captured in the Aquidauana River, in the State of Mato Grosso do Sul.

\section{Material and Methods}

Two-day monthly expeditions were conducted during the years 2003 and 2004, bimonthly as well as in October 2005 in the Aquidauana River, Camisão District ( $20^{\circ} 29^{\prime}$ 08.7' $\mathrm{S}$ and $55^{\circ} 38^{\prime}$ '42' W), in the State of Mato Grosso do Sul. However, the animals were only captured in the following months: September and November 2003, October 2004 and October 2005. The fish were captured by net, mesh size 6 and $17 \mathrm{~cm}$ between opposed knots. They were then killed by cerebral commotion, measured to obtain total weight $(\mathrm{g})$, total and standard length $(\mathrm{cm})$. After that, necropsy was conducted to determine sex and the intestines were separated to perform microscopic analysis and to collect the parasites.

The helminths collected were processed according to Eiras et al. (2000) and identified following Travassos et al. (1928), Yamaguti (1961), Anderson et al. (1974), Thatcher (1991), Khalil et al. (1994), Chambrier and Vaucher (1999), Rego et al. (1999) and Vicente and Pinto (1999).
The alometric condition factor was calculated using the following formula $\mathrm{K}_{\mathrm{a}}=\mathrm{W} / \mathrm{L}^{\mathrm{b}}$ where $\mathrm{W}=$ weight; $\mathrm{L}=$ total length and $\mathrm{b}=$ slope of the ratio weight/length, which is estimated by the equation $y=a x^{b}$.

To describe the structure of the infra-communities, data related to parasite abundance and prevalence was used, as well as to species richness, according to Bush et al. (1997), in addition to ecological indexes and statistical tests that are described as follows. The Importance Value (Bush and Holmes, 1986) based on prevalence was used to verify the importance of each species of the endohelminth community. Species whose prevalence was higher than $66.66 \%$ were considered as central, between 33.33 and $66.66 \%$, secondary, and less than $33.33 \%$, satellite. The Simpson dominance index (C) was calculated to indicate dominance among parasite species, dominance being accepted when $\mathrm{C} \geq 0.25$ (Stone and Pence, 1978). The Green dispersion index (GI) was used to evaluate the dispersion pattern of parasite species. The dispersion index was tested using statistical d. Distribution was classified as aggregated when $\mathrm{d}>1.96$; regular when $\mathrm{d}<-1.96$ and random when $\mathrm{d}<1.96$ (Ludwig and Reynolds, 1988). The Brillouin diversity index was used to determine community diversity; and the $\mathrm{X}^{2}$ test determined the interspecific associations between pairs of species found in the same host. The Spearman rank correlation coefficient (rs) was used to verify if parasite abundance, condition factor and diversity were correlated with host total length and to establish the correlation between parasite species abundance for each pair (Zar, 1996). Pearson's linear correlation (r) determined the correlation between host total length and parasite prevalence, where the prevalence data were previously arc sin $\sqrt{\mathrm{X}}$ transformed (Zar, 1996). Total length data were distributed in five class sizes at $10 \mathrm{~cm}$ intervals. The $\mathrm{G}$ loglikelihood test (using the contingency table $2 \times 2$ ) was used to determine the effect of host sex on prevalence and Mann-Whitney's (U) test to determine the effect of host sex on abundance of each species (Zar, 1996). The analysis included only endohelminth species whose prevalence was higher than $10 \%$ (Bush et al., 1990). The statistical significance level adopted was $\mathrm{p} \leq 0.05$.

\section{Results}

From the 33 P. fasciatum analysed, 10 were females and 23 males. The weight and length varied between 2,300 and 9,250 g, and 57 and $103 \mathrm{~cm}$, respectively. A total of 1,228 helminth specimens, representing 10 species, were found in fish intestines and mesentery, from which $73.29 \%$ were cestodes and $26.54 \%$ nematodes. Digenean and acantocephala displayed prevalence lower than $10 \%$ and therefore, were not used in the statistical analysis.

All of the cestode species present were found in the intestines (Peltydocotyle rugosa, Harriscolex kaparari, Spatulifer rugosa, Choanoscolex abscisus, Megathylacus travassosi and Nomimoscolex sudobim), 
as well as the nematode Cucullanus sp. Only the species Contracaecum sp. Type 1 was found in the mesentery.

The species with higher mean intensity and abundance were Contracaecum sp. Type 1, S. rugosa and C. abscisus. While the last two together with $N$. sudobim were the most prevalent (Table 1). The highest prevalence amongst endohelminth was observed for C. abscisus, $69.9 \%$. According to importance value, only this species was considered central and, among cestodes, only $P$. rugosa was considered satellite, while all the others were secondary. Among the nematodes found, Cucullanus sp. was considered secondary species and Contracaecum sp. Type 1, satellite. Simpson's index indicated dominance among the endohelminth infracommunity ( $\mathrm{C}=1.0792)$, with $C$. abscisus, the dominant species. All endohelminth species found showed aggre- gated distribution pattern according to Green's index (Table 2).

With the exception of one fish specimen, all the others were found to be infected with at least one endohelminth species. The largest number of helminth species found in the intestine and/or mesentery of a single host was seven. From the sampled hosts, $69.69 \%$ were found to have between two and five endohelminth species. Mean diversity was $\mathrm{H}=0.5517$ (0-1.4478), with standard deviation 0.4209 , while the majority of the infracommunities registered higher than mean diversity.

From the 28 possible associations, 19 were positive and from these, the pairs $H$. kaparari/S. rugosa and $S$. rugosa/M. travassosi were significant. Four pairs (P. rugosalH. kaparari, P. rugosa/S. rugosa, H. kaparari/S. rugosa, S. rugosa/C. abscisus) present-

Table 1. Locale of infection, developmental stage, mean intensity, abundance, prevalence and importance of endohelminths in 33 specimens of Pseudoplatystoma fasciatum captured in the Aquidauana River, State of Mato Grosso do Sul, during September and November, 2003 and October, 2004 and October, 2005.

\begin{tabular}{|c|c|c|c|c|c|c|c|c|c|}
\hline Parasite species & LI & DS & IF & NP & MI & MA & $\mathbf{A A}$ & $\mathbf{P}(\%)$ & I \\
\hline \multicolumn{10}{|l|}{ Digenea } \\
\hline Sp.1 & I & $\mathrm{L}$ & 1 & 1 & 1 & 0.031 & - & 3.03 & $\mathrm{Sa}$ \\
\hline \multicolumn{10}{|l|}{ Cestoda } \\
\hline Peltydocotyle rugosa & I & A & 9 & 56 & 6.22 & 1.70 & $1-17$ & 27.27 & $\mathrm{Sa}$ \\
\hline Harriscolex kaparari & I & A & 12 & 93 & 7.75 & 2.82 & $1-40$ & 36.36 & $\mathrm{Se}$ \\
\hline Spatulifer rugosa & I & A & 13 & 218 & 16.80 & 6.61 & $1-55$ & 39.39 & $\mathrm{Se}$ \\
\hline Choanoscolex abscisus & I & L e A & 23 & 360 & 15.60 & 10.91 & $1-193$ & 69.69 & $\mathrm{Ce}$ \\
\hline Megathylacus travassosi & I & L e A & 11 & 47 & 4.27 & 1.42 & $1-19$ & 33.33 & $\mathrm{Se}$ \\
\hline Nomimoscolex sudobin. & I & A & 15 & 78 & 5.20 & 2.36 & $1-16$ & 45.45 & $\mathrm{Se}$ \\
\hline \multicolumn{10}{|l|}{ Nematoda } \\
\hline Cucullanus sp. & I & A & 12 & 80 & 6.67 & 2.42 & $1-17$ & 36.36 & $\mathrm{Se}$ \\
\hline Contracaecum Type 1 & M & $\mathrm{L}$ & 8 & 233 & 29.10 & 7.06 & $1-137$ & 24.24 & $\mathrm{Sa}$ \\
\hline \multicolumn{10}{|l|}{ Acantocephala } \\
\hline Sp.1 & I & A & 1 & 1 & 1 & 0.03 & - & 3.03 & $\mathrm{Sa}$ \\
\hline
\end{tabular}

LI - locale of infection (I - intestine; M - mesentery); DS - developmental stage (L - larva; A - adult); IF - number of infected fish; NP - number of parasites; MI - mean intensity of parasite; MA - mean abundance of parasite; AA - amplitude of abundance variation $\mathrm{P}(\%)$ - prevalence; I - species importance based on prevalence $(\mathrm{P}>60 \%=$ central $(\mathrm{Ce})$; $\mathrm{P}<33 \%=$ satellite $(\mathrm{Sa}) ; \mathrm{P}$ between $33 \%$ and $66 \%=$ secondary $(\mathrm{Se}))$.

Table 2. Values of Dispersion Index, Green Index and statistical d of endoparasites of 33 specimens of Pseudoplatystoma fasciatum, captured in the Aquidauana River, State of Mato Grosso do Sul. (d > $1.96=$ aggregated distribution; $\mathrm{d}<-1.96=$ regular distribution; $\mathrm{d}<1.96=$ random distribution, according to Ludwig and Reynolds, (1988)).

\begin{tabular}{lrrcc}
\hline \multicolumn{1}{c}{ Parasites } & ID & IG & d & Distribution type \\
\hline Peltydocotyle rugosa & 10.662 & 0.176 & 18.185 & aggregated \\
Harriscolex kaparari & 19.837 & 0.205 & 27.693 & aggregated \\
Spatulifer rugosa & 27.304 & 0.121 & 33.865 & aggregated \\
Choanoscolex abscisus & 106.610 & 0.294 & 74.664 & aggregated \\
Megathylacus travassosi & 9.261 & 0.179 & 16.408 & aggregated \\
Nomimoscolex sudobin & 8.324 & 0.095 & 15.144 & aggregated \\
Contracaecum Type 1 & 105.540 & 0.520 & 73.081 & aggregated \\
Cucullanus sp. & 8.302 & 0.0924 & 15.114 & aggregated \\
\hline
\end{tabular}


ed significant positive correlation between abundances (Table 3).

Significant negative correlations were found between total length and prevalence and between total length and parasite abundance for Peltydocotyle rugosa $(\mathrm{r}=-0.9363$ and $\mathrm{p}=0.0191 ; \mathrm{rs}=-0.3845$ and $\mathrm{p}=0.0271)$ and Nomimoscolex sudobim $(\mathrm{r}=-0.9768$ and $\mathrm{p}=0.0042$; $\mathrm{rs}=-0.4314$ and $\mathrm{p}=0.0121$ ) (Table 4). No significant correlation was found either between condition factor and parasite abundance, total length and diversity, or diversity and total length.

The host's sex did not affect diversity and parasite abundance (Table 5). However, the prevalence of $H$. kaparari was significantly higher in male hosts.

\section{Discussion}

The higher occurrence of Proteocephalid in this study is probably related to the carnivorous feeding habits of the hosts, which is one of the factors that influences most the composition of the parasite fauna, considering that most of the parasite intermediate hosts are found in the diet of the definitive host, such as with the case here investigated (Dogiel, 1970).

According to Resende et al. (1996) P. fasciatum feed on several smaller fish species. And the diet of $P$. fasciatum captured in Miranda River is made up of at least seven species of fish according to data from EMBRAPA (1991). Such diversity of feeding items can cause the host $P$. fasciatum to meet in them the interme-

Table 3. Values of Spearman correlation coefficient correlation (rs) and $\mathrm{X}^{2}$ test to evaluate, respectively, species correlation abundance for each pair and species pair associations of endohelminths found in 33 specimens of Pseudoplatystoma fasciatum, captured in the Aquidauana River, State of Mato Grosso do Sul.

$\mathrm{X}^{2}$

\begin{tabular}{|c|c|c|c|c|c|c|c|c|}
\hline Parasite species & (1) & (2) & (3) & (4) & (5) & (6) & (7) & (8) \\
\hline $\begin{array}{l}\text { Peltydocotyle } \\
\text { rugosa (1) }\end{array}$ & - & (+) 3.275 & (+) 2.445 & (+) 0.037 & (+) 1.547 & (+) 1.223 & (+) 0.994 & (-) 0.084 \\
\hline $\begin{array}{l}\text { Harriscolex } \\
\text { kaparari (2) }\end{array}$ & $0.3971^{*}$ & - & (+) $7.007 *$ & (+) 0.801 & (+) 3.683 & (-) 0.481 & (-) 0.011 & (-) 0.119 \\
\hline $\begin{array}{l}\text { Spatulifer } \\
\text { rugosa (3) }\end{array}$ & $0.4061 *$ & $0.6226^{*}$ & - & (+) 3.576 & (+) $5.727^{*}$ & (+) 0.179 & (+) 0.028 & (-) 0.293 \\
\hline $\begin{array}{l}\text { Choanoscolex } \\
\text { abscisus (4) }\end{array}$ & 0.1216 & 0.3050 & $0.4006^{*}$ & - & (+) 0.448 & (+) 0.001 & (+) 0.012 & (-) 3.366 \\
\hline $\begin{array}{l}\text { Megathylacus } \\
\text { travassosi (5) }\end{array}$ & 0.2785 & $0.3748^{*}$ & $0.5354 *$ & 0.2468 & - & (+) 0.138 & (+) 0.147 & (-) 3.486 \\
\hline $\begin{array}{l}\text { Nomimoscolex } \\
\text { sudobin (6) }\end{array}$ & 0.1468 & -0.2794 & -0.0199 & -0.1083 & -0.0573 & - & (-) 0.001 & (+) 0.012 \\
\hline Cucullanus sp. (7) & 0.1444 & -0.0338 & 0.0804 & -0.0512 & 0.1421 & -0.0196 & - & (-) 0.119 \\
\hline $\begin{array}{l}\text { Contracaecum } \\
\text { Type } 1(8)\end{array}$ & -0.0754 & -0.0994 & -0.2075 & -0.3249 & $-0.3854 *$ & 0.0336 & -0.1487 & - \\
\hline
\end{tabular}

rs

*Significant values for $\mathrm{X}^{2}$ and $\mathrm{rs},>3.84 \mathrm{e} \leq 0.05$, respectively.

Table 4. Values of Pearson's linear correlation (r) and by Spearman rank correlation coefficient (rs) to evaluate respectively, the relationship between total length and parasite prevalence and abundance in 33 specimens of Pseudoplatystoma fasciatum, captured in the Aquidauana River, State of Mato Grosso do Sul.

\begin{tabular}{lllll}
\hline \multicolumn{1}{c}{ Parasites } & r & p & rs & p \\
\hline Peltydocotyle rugosa & -0.9363 & $0.0191^{*}$ & -0.3845 & $0.0271^{*}$ \\
Harriscolex kaparari & -0.8353 & 0.0782 & -0.1919 & 0.2846 \\
Spatulifer rugosa & -0.8233 & 0.0867 & -0.1725 & 0.3370 \\
Choanoscolex abscisus & -0.8356 & 0.0780 & -0.0295 & 0.8705 \\
Megathylacus travassosi & -0.4831 & 0.4097 & 0.1050 & 0.5607 \\
Nomimoscolex sudobin & -0.9768 & $0.0042^{*}$ & -0.4314 & $0.0121^{*}$ \\
Contracaecum Type 1 & 0.8122 & 0.0949 & 0.1439 & 0.4242 \\
Cucullanus sp. & -0.0540 & 0.9313 & 0.1323 & 0.4630 \\
\hline
\end{tabular}

\footnotetext{
*Significant values $\mathrm{p}<0.05$
} 
Table 5. Values of Mann-Whitney tests (U) and G Log-likelihood to evaluate the relationship between sex and parasite abundance and prevalence in 33 specimens of Pseudoplatystoma fasciatum, captured in the Aquidauana River, State of Mato Grosso do Sul.

\begin{tabular}{lcccc}
\hline \multicolumn{1}{c}{ Parasites } & $\mathbf{Z}(\mathbf{U})$ & $\mathbf{p}$ & $\mathbf{G}$ & $\mathbf{p}$ \\
\hline Peltydocotyle rugosa & 1.2340 & 0.2172 & 2.4511 & 0.1174 \\
Harriscolex kaparari & 1.6649 & 0.0959 & 4.9189 & $0.0266^{*}$ \\
Spatulifer rugosa & 0.0392 & 0.9688 & 0.0022 & 0.9625 \\
Choanoscolex abscisus & 1.5277 & 0.1266 & 2.5371 & 0.1112 \\
Megathylacus travassosi & 0.1763 & 0.8601 & 0.2825 & 0.5950 \\
Nomimoscolex sudobin & 0.1959 & 0.8447 & 0.1731 & 0.6774 \\
Contracaecum Type 1 & 0.4309 & 0.6665 & 0.2524 & 0.6154 \\
Cucullanus sp. & 0.2938 & 0.7689 & 0.0814 & 0.7754 \\
\hline
\end{tabular}

*Significant value $\mathrm{p}<0.05$.

diate hosts of cestodes (Pavanelli et al., 2002). Studies of the community structure of other species of carnivorous Pimelodid, also found higher prevalence of these proteocephalid in the parasite community (Machado et al., 1996; Takemoto and Pavanelli, 2000; Guidelli et al., 2003).

With the exception of Contracaecum sp. and digenean larvae, $90 \%$ of the parasite species were in the adult developmental stages and were found in the intestines, thus indicating this to be the definitive host. All the specimens of Contracaecum sp. were located in the mesentery and corresponded to larval stage Type 1 (Moravec et al., 1992), which indicates that $P$. fasciatum is an important intermediate host for this alogeneous endohelminth species. Mean intensity data (29.13) and prevalence $(24.24 \%)$ found in this study, for this parasite, are somewhat higher than the values reported by Machado et al. (1996), who observed prevalence of $8.18 \%$ and mean intensity of 3.2 for Contracaecum sp. Type 1 in $P$. corruscans from Paraná River. Martins et al. (2003) also observed lower mean intensity of this parasite in Cichla ocellaris, Hoplias malabaricus and in Plagioscion squamosissimus from Paraná River, when compared to the present study. However, they observed that prevalence of Contracaecum sp. reached $70 \%$ during September in H. malabaricus.

The low number of fish infected with digenean larvae may have been due to the period of harvesting, since the fish were captured only during September, October and November, or even, because $P$. fasciatum works as a paratenic and/or intermediate host for this group of parasites. Some endoparasites have a very complex life cycle, and are transmitted by means of interactions between prey-predator and the presence or absence of these parasites in the hosts represents the occurrence or not in the ecosystem of all these organisms necessary to complete the life cycle of these parasites (Marcogliese and Cone, 1996). In addition, there are no studies about the population dynamics of intermediate hosts that could help to understand the parasite communities in fish.
A single individual adult acantocephala was observed in the intestine of one fish. The life cycle of acanthocephalans involves arthropods like Ostracoda and Copepode as intermediate hosts and fishes as definitive hosts. The low number of fish infected with acantocephala may indicate that $P$. fasciatum is an accidental host to acantocephalans or may have been due to the period of capture. It might be that in this period, the intermediate hosts of acantocephalans did not occur in great number in this environment.

With the importance value based on prevalence only, C. abscisus was considered the central species, and its dominance was confirmed by Simpson's index. This species was the most abundant in this study, and a similar result was found for $P$. corruscans captured in Paraná River by Machado et al. (1996). The other species were classified in different categories, H. kaparari, M. travassosi, $S$. rugosa and $N$. sudobim were classified as secondary species and $P$. rugosa as satellite. The high prevalence of $C$. abscisus may have been due to the fact of the intermediate host being the main diet of $P$. fasciatum since helminths from fish are acquired by ingestion of intermediate hosts which are part of their diet.

The high number of parasites that presented aggregated distribution for $P$. fasciatum is a typical pattern for freshwater parasites as has been shown by other authors (Machado et al., 1996; Brasil-Sato, 1999; Guidelli et al., 2003; Lizama et al., 2005). This aggregated distribution pattern, according to Holmes (1990) may be due to increasing reproductive efficiency of some adult species of parasites and occupation of a different niche in the intestine host. According to Dobson (1990), this distribution pattern improves the opportunity to infect the host. This distribution pattern can influence the evolutionary history of parasites due to competition for food and space and also to reproductive success (Poulin, 1998).

The positive association between species pairs, as observed for H. kapararil S. rugosa and S. rugosal $M$. travassosi, indicates that the species coexist in the same host without competition with respect to ecological requirements, probably because they do not occupy 
the same niche along the intestines. In addition, coexistence may be associated with the fact that they have the same intermediate host. The occupation of interior niches in the intestine may be influenced by several factors, among them, competition between species, utilization of nutrients by the parasites (Holmes, 1990), stress (Williams et al., 1991), seasonal changes and fish age (Shotter, 1973).

According to Bush and Holmes (1986), increase of the infected area in the intestine occurs when the parasite population also increases. This fact was also verified by Pavanelli and Takemoto (2000) while analyzing gastrointestinal distribution of parasites in the intestines of Sorubim lima, the most abundant species of cestode was distributed along the entire organ, while other species showed preference for certain regions.

Esch et al. (1990) reported that the parasite community may be influenced by the age and length of the host, changes in the diet, in the volume of food ingested, ontogenetic changes in the immuno-competence and also, changes in probability of contact with intermediate hosts.

In the present study, fish total length varied between 57 and $103 \mathrm{~cm}$ and significant negative correlations were observed between total length and parasite prevalence and abundance for both, P. rugosa and N. sudobim, thus suggesting that not always in larger fishes there is increase in the level of parasitism. The other species of parasite did not present any correlations. However, in the literature there are reports of significant correlations in studies performed with other carnivore Siluriformes (Machado et al., 1994; Takemoto and Pavanelli, 2000; Guidelli et al. 2003), and negative correlations between fish length and level of parasitism have been registered for other species (Oliva et al., 1990).

Luque and Chaves (1999) suggest that generalizations about the influence of the host size should be avoided. Parasitism should not necessarily be more pronounced in larger fish due to accumulation and longer period of exposition to infection. Negative correlations may occur when the fish acquire the parasites at a younger age and eliminate them when adult (Valtonen et al., 1990), by changes in the ingestion of forage species in different age bracket population and by the population dynamics of intermediate hosts (Luque and Chaves, 1999).

The prevalence of $H$. kaparari depended on the host sex, with the male hosts being infected at a higher rate. This result is similar to reports by Takemoto and Pavanelli (2000), who observed higher prevalence of cestodes in the males of Sorubim lima. Differences in the levels of infection between males and females of the same species may be explained by behavioral differences. This may have happened in the present study, considering that all the sampled fish were captured during the reproductive period. $P$. fasciatum is a reofilic fish, that migrates during the reproduction season, when the females go upriver searching for adequate places to spawn, they swim close to the river banks, where the vegetation is more dense and possibly, with less available food. In addition, the females reduce the search for food, during migration. This behavioral change may influence the parasite infracommunity, since the females may ingest different food altogether or diminish ingestion.

\section{Conclusions}

At least 10 endohelminth species may infect $P$. fasciatum from the Aquidauana River.

The most prevalent, more abundant and average intensity species was $C$. abscisus, which was classified as the central dominant species.

The parasites of $P$. fasciatum from the Aquidauana River showed an aggregated distribution pattern.

Significant positive associations were observed between abundances of the pairs $H$. karapari/S. rugosa and S. rugosa/M. travassossi.

The prevalence of $H$. karapari was significantly higher for male hosts.

Acknowlegdements - This work is part of the first author's Doctorate thesis, supported with a grant from CAPES.

\section{References}

ANDERSON, RC., CHABAUD, AG. and WILLMOTT, S., 1974. CIH Keys to the nematode parasites of vertebrates. England: Commonwealth Agricultural Bureaux.

BRASIL-SATO, MC., 1999. Ecologia das comunidades de parasitos metazoários de Pimelodus maculatus Lacépède, 1803 (Siluriformes: Pimelodidae) das bacias do rio São Francisco, Três Marias, $M G$, e do rio Paraná, Porto Rico, PR. São Carlos: Universidade Federal de São Carlos - UFSCar. 255p. Tese de Doutorado.

BUSH, A. and HOLMES, JC., 1986. Intestinal helminthes of lesser scaup ducks: patterns of association. Canadian Journal Zoology, vol. 64, p. 132-141.

BUSH, A., AHO, JM. and KENNEDY, CR., 1990. Ecological versus phylogenetic determinants of helminth parasite community richness. Evolutionary Ecology, vol. 4, p. 1-20.

BUSH, A., LAFFERTY, KD., LOTZ, JM. and SHOSTAK, AW., 1997. Parasitology meets ecology on its own terms: Margolis et al. revisited. Journal of Parasitology, vol. 83, no. 4, p. $575-583$

DeCHAMBRIER,A.andVAUCHER,C.,1999.Proteocephalidae et Monticelliidae (Eucestoda: Proteocephalidea) parasites de poissons d'eau douce au Paraguay, avec descriptions d'un genre et de dix espèces nouvelles. Revue Suisse de Zoologie, vol. 106, no. 1, p. 165-254.

DOBSON, AP., 1990. Models of multi-species parasiteshost communities. In ESCH, GW., BUSH, AO. and AHO, J. (Eds.). Parasite communities: patterns and process. New York: Chapman and Hall. p. 261-287.

DOGIEL, VA., 1970. Ecology of the parasites of freshwater fishes. In DOGIEL, VA., PETRUSHEVSKI, GK. and POLYANSKY, YI. (Eds.). Parasitology of fishes. London: Olivier \& Boyd. p. 1-47.

EIRAS, JC., TAKEMOTO, RM. and PAVANELLI, GC., 2000. Métodos de estudo e técnicas laboratoriais em parasitologia de peixes. Maringá: EDUEM. 171p. 
Empresa Brasileira de Pesquisa Agropecuária - EMBRAPA, 1991. Avaliação da contaminação ambiental da bacia hidrográfica do rio Miranda: relatório final. Corumbá: EMBRAPA. 174p. Centro de pesquisa agropecuária do Pantanal (Corumbá, MS).

ESCH, GW., SHOSTAK, AW., MARCOGLIESE, DJ. and GOATER, TM., 1990. Patterns, and processes in helminth parasite communities: an overview. In ESCH, GW., BUSH, AO. and AHO, J. (Eds.). Parasite communities: patterns and processes. New York: Chapman and Hall. p. 1-19.

GUIDELLI, GM., ISAAC, A., TAKEMOTO, RM. and PAVANELLI, GC., 2003. Endoparasite infracommunities of Hemisorubim platyrhynchos (Valenciennes, 1840) (Pisces: Pimelodidae) of the baía river, upper Paraná River floodplain, Brazil: specific composition and ecological aspects. Revista Brasileira de Biologia = Brazilian Journal of Biology, vol. 63, no. 2, p. 261-268.

HOLMES, JC., 1990. Competition, contacts and other factors restricting niches of parasitc helminths. Annales de Parasitologie Humaine et Comparee, vol. 65, p. 69-72.

KHALIL, L.F., JONES,A. and BRAY, R.A. 1994. Keys to the cestode parasites of vertebrates. St. Albans: CAB International. 751p.

LIZAMA, MAP., TAKEMOTO, RM. and PAVANELLI, GC., 2005. Influence of host sex and age on infracommunities of metazoan parasites of Prochilodus lineatus (Valenciennes, 1836) (Prochilodontidae) of the upper Paraná River floodplain, Brazil. Parasite, vol. 12, p.299-304.

LUDWIG, JA. and REYNOLDS, JF., 1988. Statistical ecology: a primer on methods and computing. New York: WileyInterscience Publications. 337p.

LUQUE, JL. and CHAVES, ND., 1999. Ecologia da comunidade de metazoários parasitos da anchova Pomatomus saltator (Linnaeus) (Osteichthyes, Pomatomidae) do litoral do estado do Rio de Janeiro, Brasil. Revista Brasileira de Zoologia, vol. 16, no. 3, p. 711-723.

MACHADO, MH., PAVANELLI, GC. and TAKEMOTO, RM., 1994. Influence of host's sex and size on endoparasitic infrapopulations of Pseudoplatystoma corruscans and Schizodon borelli (Osteichthyes) of the high Paraná river, Brazil. Revista Brasileira de Parasitologia, vol. 3, no. 2, p. 143-148.

MACHADO, MH., PAVANELLI, GC. and TAKEMOTO, RM., 1996. Structure and diversity of endoparasitic infracommunities and the trophic level of Pseudoplatystoma corruscans and Schizodon borelli (Osteichthyes) of the high Paraná river. Memórias do Instituto Oswaldo Cruz, vol. 91, no. 4, p. $441-448$.

MARCOGLIESE, DJ. and CONE, DK., 1996. On the distribution and abundance of eel parasites in Nova Scotia: influence of $\mathrm{pH}$. Journal of Parasitology, vol. 82, no. 3, p. 389-399.

MARTINS, ML., SANTOS, RS., TAKAHASHI, HK., MARENGONI, NG. and FUJINMOTO, RY., 2003. Infection and susceptibility of three fish species from the Paraná River, Presidente Epitácio, State of São Paulo, Brazil to Contracaecum sp. larvae (Nematoda: Anisakidae). Acta Scientiarium, vol. 25, no. 1, p. 73-78.

MORAVEC, F., KOHN, A. and FERNANDES, BMM., 1992. Nematode parasites of fishes of the Paraná River, Brazil. Part 1. Trichuroidea, Oxyuroidea and Cosmocercoidea. Folia Parasitologica, vol. 39, p. 327-353.

OLIVA, M., LUQUE, JL. and IANNACONE, JA., 1990. The metazoan parasites of Stellifer minor (Tschudi, 1844): an ecological approach. Memórias do Instituto Oswaldo Cruz, vol. 85, no. 3, p. 271-274.

PAVANELLI, GC. and TAKEMOTO, RM., 2000. Aspects of the ecology of proteocephalid cestodes, parasites of Sorubim lima (Pimelodidae), of the upper Paraná River, Brazil: II. Interspecific associations and distribuition of gastrintestinal parasites. Revista Brasileira de Biologia = Brazilian Journal of Biology, vol. 60, no. 4, p. 885-590.

PAVANELLI, GC., EIRAS, JC. and TAKEMOTO, RM., 2002. Doenças de peixes: profilaxia, diagnóstico e tratamento. 2 ed. Maringá: EDUEM; NUPÉLIA. 305p.

POULIN, R., 1998. Evolutionary ecology of parasites: from individuals to communities. Londres: Chapman \& Hall.

REGO, AA., CHUBB, JC. and PAVANELLI, GC., 1999. Cestodes in South American freswater teleost fishes: keys to genera and brief description of species. Revista Brasileira de Zoologia, vol. 16, no. 2, p. 299-367.

RESENDE, EK., PEREIRA, RAC., ALMEIDA, VLL. and SILVA, AG., 1996. Alimentação de peixes carnívoros da planície inundável do rio Miranda, Pantanal, Mato Grosso do Sul, Brasil. Corumbá: EMBRAPA; CPAP. 36p. Boletim de Pesquisa, 03.

SANTOS, SMC., CECCARELLI, PS. and RÊGO, RF., 2003. Helmintos em peixes do Pantanal sul-mato-grossense: primeira expedição do Programa Pantanal. Boletim Técnico do CEPTA, vol. 16, p. 15-26.

SHOTTER, RA., 1973. Changes in the parasite fauna of Odontogadus merlangus L. with age and sex of host, season, and from different areas in the vicinity of the Isle of Man. Journal of Fish Biology, vol. 5, p. 559-573.

STONE, JE. and PENCE, DB., 1978. Ecology of helminth parasitism in the bobcat from West Texas. Journal of Parasitology, vol. 64, no. 2, p. 295-302.

TAKEMOTO, RM. and PAVANELLI, GC., 2000. Aspects of the ecology of proteocephalid cestodes parasites of Sorubim lima (Pimelodidae), of the upper Paraná River, Brazil: I. Structure and influence of host's size and sex. Revista Brasileira de Biologia = Brazilian Journal of Biology, vol. 60, no. 4, p. 577-584.

THATCHER, VE., 1991. Amazon fish parasites. Manaus: Instituto Nacional de Pesquisas da Amazônia.

TRAVASSOS, L., ARTIGAS, P. and PEREIRA, C., 1928. Fauna helmintológica dos peixes de água doce do Brasil. Arquivos do Instituto Biológico, vol. 1, p. 5-67.

VALTONEN, ET., ROST, M. and RAHKONEM, R., 1990. Seasonality of two gill monogeneas from two freshwater fish from an oligotrophic lake in northeast Finland. International Journal of Parasitology, vol. 20, no. 1, p. 101-107.

VICENTE, JJ. and PINTO, RM., 1999. Nematóides do Brasil. Nematóides de peixes. Atualização: 1985-1998. Revista Brasileira de Zoologia, vol. 16, no. 3, p. 561-610.

WILLIAMS, EH., BUNKLEY-WILLIAMS, L., DOWGIALLO, MJ. and DYER, WG., 1991. Influence of collection methods on the occurrence of alimentary canal helminth parasites in fish. Journal of Parasitology, vol. 77, no. 6, p. 1019-1022.

YAMAGUTI, S., 1961. Systema Helminthum. New York; London; Sydney: Interscience Publishers, v.5.

ZAR, JH., 1996. Biostatistical Análisis. 3 ed. New Jersey: Prentice-Hall, Inc. 662p. 